Roman Mazur

Uniwersytet Papieski Jana Pawła II w Krakowie

\title{
Rozeznanie w Piśmie Świętym. Terminologia, podmiot, przedmiot i narzędzia
}

\section{Wprowadzenie}

Rozeznanie jest istotną cechą człowieka. Kwestią oczywistą pozostaje więc to, że tematyka ta jest obecna w Biblii. Jednak jej prezentacja oraz rozumienie cechują się wpływem wielu kultur i dodatkowo wiedzą przekraczającą doświadczenie jedynie ludzkie. Pomocne w przedstawieniu rozeznania w Bibliibędzie najpierw (I) ukazanie bazy pojęciowej (hebrajskiej i greckiej), dzięki której idea staje się zrozumiała również dla człowieka współczesnego. Następnie uwaga zostanie skierowana na (II) podmiot rozeznający, którym w Biblii jest Bóg i człowiek, ze wskazaniem wspólnych elementów pozwalających na dokonanie rozeznania. Krokiem kolejnym będzie zatrzymanie się nad (III) przedmiota- 
mi czy też obszarami, które domagają się rozeznania i z tego powodu stają się przedmiotem akceptacji lub odrzucenia przez człowieka lub Boga. Natomiast (IV) narzędzia lub środki rozeznania skoncentrują się na sposobie i możliwości realizacji rozeznania jako oceny, a w efekcie możliwości i konieczności dokonywania wyborów moralnych w świetle otrzymanych darów Bożych.

\section{Terminologia}

Pierwszym, w zasadzie najłatwiejszym etapem związanym $z$ ujęciem rozeznania $\mathrm{w}$ Biblii jest terminologia. Wstępnie przedstawimy pojęcia używane przez języki biblijne, dzieląc je na dwa etapy chronologiczne: Stary i Nowy Testament. Terminy zostaną przedstawione w porządku alfabetycznym odpowiednich języków.

\section{Stary Testament}

1.1.] רִּ (czyt. 'bin') oraz termin pokrewny z tej samej rodziny binah.

biyn - to czasownik, którego znaczenie brzmi: „rozeznać” (np. Rdz 41,33; Prz 10,13), „dostrzec”, „zaobserwować”, „Zwrócić uwagę” (np. Pwt 32,7; Ps 5,2), „być dyskretnym”, „być inteligentnym” (np. 2 Krn 11,23; Iz 29,16; Ps 119,100), „rozumieć” (np. Jr 9,11; Da 10,1; Iz 44,18)1. Z kolei binah - to rzeczownik, który oznacza „rozumienie”. Spotykamy go w kontekście oznaczającym „rozumienie słów” (np. Prz 1,2) i „rozumienie ludzi” (np. Prz 30,2)2. Imiesłów prezentowanego czasownika,

${ }^{1}$ Por. ad vocem בין, [w:] The Hebrew and Aramaic Lexicon of the Old Testament, vol. I (dalej: HALOT), eds. L. Koehler, W. Baumgartner, tr. M.E.J. Richardson (English Redaction), Leiden 1994, s. 122-123; T.E. Fretheim, ad vocem [w:] New International Dictionary of Old Testament Theology and Exegesis, vol. I (dalej: NIDOTTE), red. W.A. Van Gemeren, Grand Rapids 1997, s. 641-642; H.H. Schmid, ad vocem בין, [w:] Theological Lexicon of the Old Testament, vol. I (dalej: TLOT), eds. E. Jenni, C. Westermann, Peabody 1997, s. 230-232.

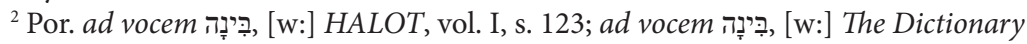
of Classical Hebrew, vol. II (dalej: DCH), ed. D.J.A. Clines, Sheffield 1995, s. 149-150. 
מֵברין (czyt. mewin), oznacza „rozumieć”, „być zdolnym do zrozumienia/ pojęcia”, „być zdolnym” i określa efekt rozeznania. Wszystkie te terminy występują w Starym Testamencie 210 razy. Spotykamy tu też nazwę własną wywodzącą się z powyższego źródłosłowu: Jabin (8 razy). Było to imię kananejskiego króla miasta Chasor (por. Joz 11,1; Sdz 4,2.24).

W ST napotykamy także na użycie tego terminu na określenie całkowitego braku „rozeznania” jako charakterystykę tzw. bóstw: „[Tacy] nie maja świadomości ani zrozumienia, gdyż [mgła] przesłonięte sa ich oczy, tak iż nie widza, i serca ich, tak iż nie rozumieja" (Iz 44,18). Pośród różnych doświadczeń i prób życiowych jedynie roztropni są w stanie zrozumieć sprawy określane jako znaki apokaliptyczne: „Wielu zostanie poddanych oczyszczeniu, wybieleniu, wypróbowaniu, ale przewrotni będa postępować przewrotnie $i \dot{z} a d e n ~ z$ przewrotnych nie zrozumie tego, lecz roztropni zrozumieja" (Da 12,10). W końcu Bóg zawsze jest w stanie dokonać właściwego rozeznania nawet najbardziej zakrytych spraw: „Ty wiesz, kiedy siadam i wstaję. $Z$ daleka przenikasz moje zamysty" (Ps 139,2) ${ }^{3}$.

1.2. טָעִ (czyt. 'taam') - oznacza „posmakować” (w celu rozeznania, rozpoznania), „rozeznać” (Wj 16,31; Lb 11,8; 1 Sm 21,14; 1 Sm 25,33 [„rozsądek”]; Jr 48,11; Jon 3,7 [„zarządzono”]; Ps 34,9 [„Skosztujcie i zobaczcie, jak dobry jest Pan, szczęśliwy człowiek, który się do Niego ucieka”] ; Ps 119,66 [Bóg jest dawcą rozsądku: „Naucz mnie zrozumienia i umiejętności, bo ufam Twoim przykazaniom"]; Hi 6,6; Hi 12,20 [Bóg może także rozsądek zabrać: „Głos uzdolnionym odbierze, rozsqdku pozbawi i starców”]; Prz 11,22 [„rozsądek”]; Prz 26,16 [„,rozumny”]). Zaznaczyć jednak należy, że znaczenie „rozeznania” lub „rozpo-

${ }^{3}$ Por. H. Ringgren, ad vocem [w:] Theological Dictionary of the Old Testament, vol. II (dalej: TDOT), ed. G.J. Botterweck, H. Ringgren, H.-J. Fabry, Grand Rapids 1975, s. 101-102.

4 Podstawą rozumienia Ps 34,9 w sensie „rozeznania” jest figura retoryczna synekdocha; por. R.H. O'Connell, ad vocem טָָָ, w: NIDOTTE, vol. II, s. 372. 
znania” jest w przypadku tego terminu znaczeniem pochodnym, choć celowo zamierzonym w Biblii ${ }^{5}$. Pojęcie to spotykamy w ST 57 razy.

1.3. חָכָ (czyt. 'hacham') oznacza „być/stawać się mądrym”, „rozumieć”, „pojmować”. Można je także rozumieć w takim sensie, że skutki „bycia mądrym”, a zarazem przyczyny takiego stanu wskazują na efekt zafunkcjonowania mądrości jako narzędzia rozeznania ${ }^{6}$. Pojęcie to występuje 138 razy w Starym Testamencie. Przymiotnikowo określa osobę „roztropną"”. Dobrym przykładem jest tutaj: „Wybierzcie sobie w waszych pokoleniach mężów rozumnych, mądrych i szanowanych, abym ich postawit wam na czele" (Pwt 1,13). Jeśli jednak weźmiemy pod uwagę efekt rozeznania - „mądrość” (חְְָָָ - czyt. hochma), to wówczas liczba referencji znacznie wzrasta (315 razy). Korzystny jest tutaj skutek przebywania („chodzenia”) w towarzystwie „mądrych nauczycieli”, gdyż jest nim stawanie się mądrzejszym ${ }^{8}$.

1.4. עיָ (czyt. 'jada') oznacza „obserwować”, stąd „wiedzieć”, „rozpoznać". Występuje on bardzo często w Starym Testamencie (1001 razy). Wachlarz znaczeniowy przechodzi od zmysłowego doświadczenia aż po intelektualny proces poznawania lub nabywania doświadczenia9. Znacząca jest tutaj możliwość „rozpoznania Boga”, czyli „rozeznania” Jego działalności, obecności lub woli ${ }^{10}$. To znaczenie jest mocno powiązane z doświadczeniem wyjścia z Egiptu jako szerokiej gamy doświadczeń działalności i obecności Boga (np. Wj 6,7; 7,5; 29,46). Elementami

${ }^{5}$ Por. ad vocem חכם, [w:] HALOT, vol. I, s. 313-314; M. Sæbø, ad vocem חכם, [w:] TLOT, vol. I, s. 418; H.-P. Müller, ad vocem חכם, [w:] TDOT, vol. IV, s. 366-368.

${ }^{6}$ Por. G.H. Wilson, ad vocem חכָד, [w:], NIDOTTE, vol. II, s. 128-129.

${ }^{7}$ Por. ad vocem חָָָז, [w:] A Hebrew and English Lexicon of the Old Testament (dalej: $B D B$ ), eds. F. Brown, S.R. Driver, C.A. Briggs, Oxford 1907, znaczenie 5.

${ }^{8}$ Por. ad vocem חָָָ, [w:] BDB, znaczenie 6.b.2.

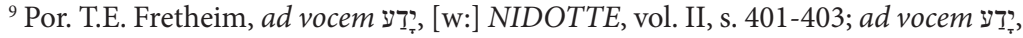
[w:] $B D B$, znaczenie 1.b-c.f.

${ }^{10}$ Por. T.E. Fretheim, ad vocem ידָידע, [w:] NIDOTTE, vol. II, s. 405-406; ad vocem עִ 
ułatwiającymi „rozpoznanie” działalności Boga są cuda (np. Pwt 4,35: „Widziałeś to wszystko, byś poznat, że Pan jest Bogiem”).

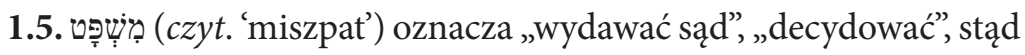
"rozeznać"11. Występuje dość często w ST (425 razy). Odnosi się tak do czynności wydawania sądu, jak i efektu tej czynności. Podmiotami działającymi są tutaj Bóg i człowiek ${ }^{12}$. Niecodzienne zadanie rozeznania posiadał Najwyższy Kapłan, posługując się pektorałem, w którym znajdowały się bliżej nieznane nam przedmioty służące dokonaniu wyboru jednej z dwóch możliwości: „Do pektorału do radzenia się wyroczni włożysz urim i tummim, aby były na sercu Aarona, gdy będzie wchodzit przed oblicze Pana. I tak będzie nosił Aaron zawsze na sercu swoim [pektorał] do radzenia się wyroczni dla Izraelitów przed obliczem Pana" (Wj 28,30). W przedstawionym przypadku uważano, że wyboru dokonuje Bóg, posługując się Najwyższym Kapłanem ${ }^{13}$ (por. Lb 27,21). Rozeznania dokonywała także społeczność dorosłych Izraelitów w przypadku nieumyślnego zabójstwa: „wtedy według powyższych zasad społeczność rozstrzygnie pomiędzy zabójca a mścicielem krwi” (Lb 35,24).

1.6. נָכָ (czyt. 'nachar') - pojęcie to oznacza „rozeznać”, stąd „rozpoznać”, „uczynić znanym”14. Jest dość rzadkie, pojawia się bowiem tylko 50 razy w ST. Najczęściej dotyczy „rozpoznania” jakiejś osoby lub przedmiotu (Rdz 27,23: „Nie rozpoznat jednak Jakuba, gdyż jego ręce były owłosione jak ręce Ezawa"). Warte wspomnienia jest użycie tego pojęcia w Iz 61,9, gdzie Izrael po dokonaniu odkupienia przez Boga zostanie „rozpoznany”, „rozeznany” jako lud, któremu Bóg błogosławi: „Plemię ich będzie znane wśród narodów, i między ludami - ich potomstwo. Wszyscy, co ich zobacza, uznają, że oni są błogosławionym szczepem Pana".

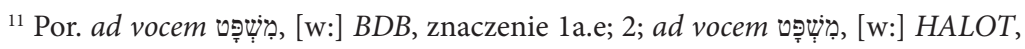
vol. II, s. 651-652, znaczenie 1.

${ }^{12}$ Por. Johnson B., ad vocem מְִׁุ, [w:] TDOT, vol. IX, s. 94-95.

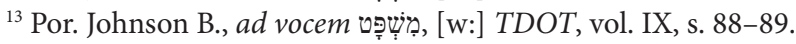

${ }^{14}$ Por. ad vocem נָָכָ I, [w:] BDB, znaczenie 1-3. 
1.7. עָרֵ (czyt. 'aram') to pojęcie bardzo rzadko występujące w Starym Testamencie (wraz z pojęciami o tej samej podstawie słowotwórczej - jedynie 22 razy). Pierwsze jego znaczenie jest negatywne: „sprytny”, „przebiegły”, „zwodniczy”, ale posiada także znaczenie „roztropny" ${ }^{15}$. To pozytywne pojawia się jedynie w Księdze Przysłów. Charakterystyczne jest tutaj np.: „Głupi gardzi karceniem ojca, kto nagany przyjmuje, jest roztropny” (Prz 15,5). Terminem tym określa się działalność cechowaną roztropnością, czyli skutek dokonanego wcześniej rozeznania. To z kolei oznacza, że rozum ludzki - choć skażony grzechem - nie jest mechanicznie ukierunkowany na zło, ale posiada zdolność rozróżniania dobra od zła ${ }^{16}$. Ciekawostką jest użycie tego pojęcia na określenie „przewrotności” węża w Rdz 3,1.

1.8. שַָָׁ (czyt. 'sahal') oznacza „rozumieć”, „czynić mądrym”, „postępować roztropnie" i występuje 60 razy w $\mathrm{ST}^{17}$. Rzeczownik spokrewniony, שְֶֶׁ (czyt. 'sehel'), oznacza „roztropność”, „rozeznanie”, "rozsądek”, ale występuje tylko 9 razy w ST ${ }^{18}$. Przykładem jest choćby: „Rozsądek źródłem życia tych, co go majq" z Prz 16,22. Określani takim

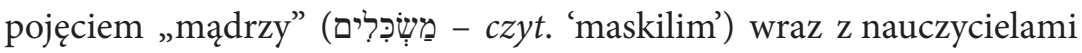
sprawiedliwości osiągną zbawienie: „Mądrzy będa świecić jak blask sklepienia, a ci, którzy nauczyli wielu sprawiedliwości, jak gwiazdy na wieki i na zawsze" (Dn 12,3) ${ }^{19}$.

\section{Nowy Testament}

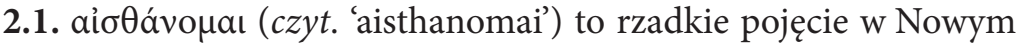
Testamencie (jedynie w Łk 9,45: „Lecz oni nie rozumieli tego powiedzenia; było ono zakryte przed nimi, tak że go nie pojęli, a bali się zapytać

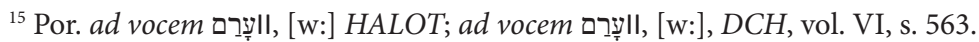

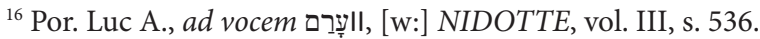

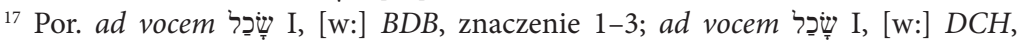
znaczenie 1a.2a-c.3, vol. VIII, s. 151-153.

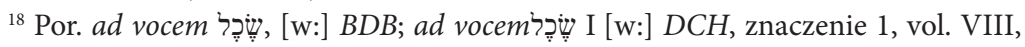
s. 153.

${ }^{19}$ Por. T.E. Fretenheim, ad vocem שָָָׁ, [w:] NIDOTTE, vol. III, s. 1240. 
Go o to powiedzenie”) precyzyjnie oznacza „rozeznanie zmysłowe” lub „duchowe rozeznanie" i ,intelektualne rozumienie"20. W LXX występuje 11 razy i zawsze odnosi się do rozeznania. Dodatkowo występu-

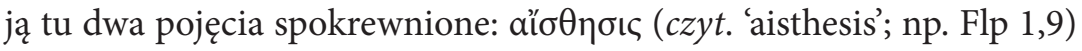

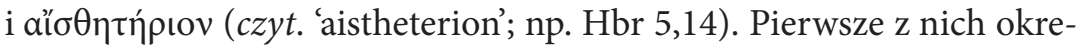
śla precyzyjnie władzę moralnego rozeznania i etycznego sądu już od czasów Eurypidesa, drugie - narzędzie rozróżnienia dobra i zła ${ }^{21}$. Dodatkowo Hbr 5,14 podkreśla wagę ćwiczenia władz umysłu osób dorosłych, aby zyskać habitus rozeznania: „dla dorosłych, którzy przez ćwiczenie maja władze umysłu zaprawione do rozróżniania dobra i zła".

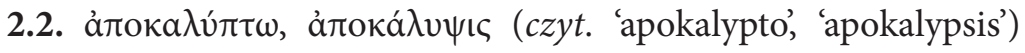
w sumie występują 45 razy w NT. Pojęcia te odzwierciedlają pierwotne pragnienie rozeznania woli Boga lub bóstw pogańskich poprzez uznane za skuteczne w tej materii przedmioty (np. fetysze) lub osoby (np. przywódców) ${ }^{22}$. W takim kontekście rozeznanie pojmowane jest jako efekt lub dar otrzymany za pośrednictwem „czegoś” lub „kogoś”23.

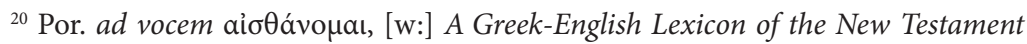
and other Early Christian Literature. Based on Walter Bauer's Griechisch-Deutsches Wörterbuchzu den Schriften des Neuen Testaments und der frühchristlichen Literatur, sixth edition; English editions by W.F. Arndt, F.W. Gingrich, F.W. Danker, 3 ed. (dalej:

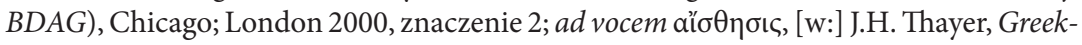

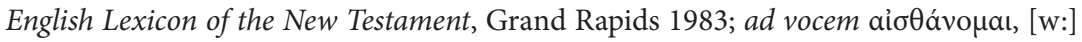
Z. Abramowiczówna, Słownik grecko-polski (dalej: Abramowiczówna), t. I, znaczenie 2,

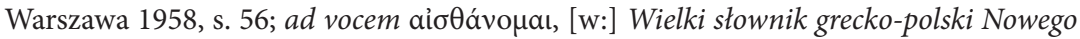
Testamentu. Wydanie z polską lokalizacja greckich haseł, kluczem polsko-greckim oraz indeksem form czasownikowych (dalej: Popowski), wyd. 4 popr., Warszawa 2006, s. 597.

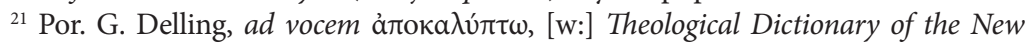
Testament, vol. I (dalej: TDNT), ed. G. Kittel, G. Friedrich, Grand Rapids 1991, s. 187-188.

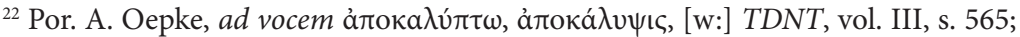
W. Mundle, ad vocem ảं of the New Testament Theology, vol. III (dalej: NIDNTT). Translated, with additions and revisions, from the German Theologisches Begriffs lexikon zum Neuen Testament, edited by L. Coenen, E. Beyreuther, H. Bietenhard, 2. ed., Brown C., Grand Rapids 1986, s. 312-316.

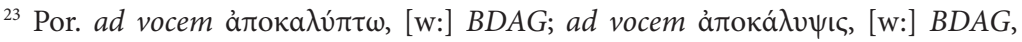
znaczenie 1. 
Można więc podkreślić, że ze względu na sposób „nabycia” rozeznania przedstawiane pojęcie określa stan przeciwny do prezentowanego bezpośrednio wcześniej. Przykład narzędzia rozeznania znajdujemy w Łk 2,32: „światło na oświecenie pogan i chwałę ludu Twego, Izraela”. Natomiast rozeznanie uzyskane dzięki działaniu Boga możemy odnotować w Mt 11,25: „Wysławiam Cię, Ojcze, Panie nieba i ziemi, że zakryteś te rzeczy przed mądrymi i roztropnymi, a objawiłeś je prostaczkom”.

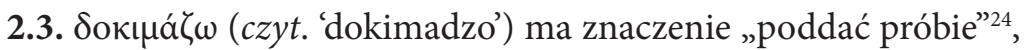
„rozeznać”, „zaakceptować”25. Występuje 22 razy w NT. Brak tego typu rozeznania prowadzi do skazania na używanie jedynie władz skażonego wcześniejszym grzechem rozumu: „A ponieważ nie uznali za słuszne zachować prawdziwego poznania Boga, wydał ich Bóg na pastwę na nic niezdatnego rozumu, tak że czynili to, co się nie godzi” (Rz 1,28). Jego stosowanie pomaga odnaleźć wolę Bożą: „Badajcie, co jest miłe Panu” (Ef 5,10; por. także 1 Tes 5,21). Pomaga także uniknąć fałszywej chęci przypodobania się ludziom, ale pozwala zachować czystą intencję działania i zaufanie do Bożej oceny: „lecz jak przez Boga zostaliśmy uznani za godnych powierzenia nam Ewangelii, tak głosimy ją, aby się podobać nie ludziom, ale Bogu, który bada nasze serca" (1 Tes 2,4 $)^{26}$.

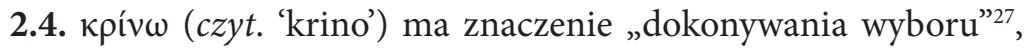
„wydawania sądu”, „wyrażania opinii”, „rozeznawania”28. Występuje 114

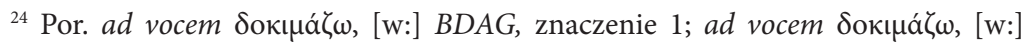

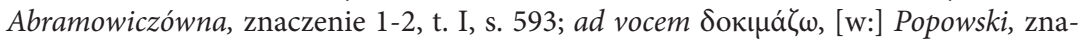
czenie 1, s. 142.

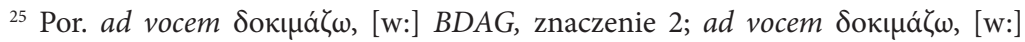

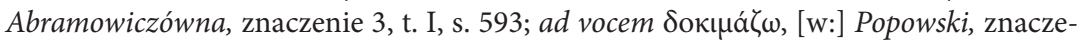
nie 1, s. 142.

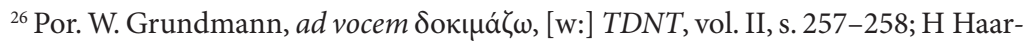

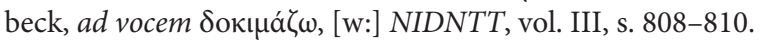

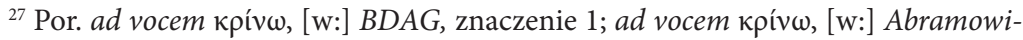

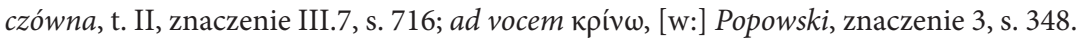

${ }^{28}$ Por. ad vocem $\kappa \rho i ́ v \omega$, [w:] BDAG, znaczenie 2 i 3; ad vocem $\kappa \rho i ́ v \omega$, [w:] Abramowi-

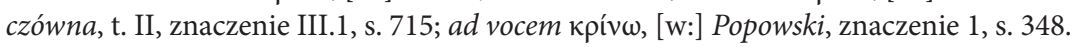




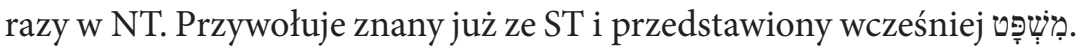
Przykładem właściwie dokonanego rozeznania (sądu) jest pochwała Jezusa skierowana do Szymona: „Szymon odpowiedział: «Przypuszczam, że ten, któremu więcej darowat». On zaś mu rzekt: «Stusznie osądziłeś»" $(Ł k 7,43)$. Nieumiejętność rozeznania znaków czasu źle świadczy o słuchaczach Jezusa i staje się powodem Jego wyrzutu: „I dlaczego sami z siebie nie rozróżniacie tego, co jest stuszne?” (Łk 12,57).

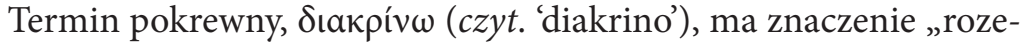
znać” ${ }^{29}$, „zwątpić” ${ }^{30}$. Można posiadać prawidłowe rozeznanie rzeczywistości, ale nie brać pod uwagę konsekwencji rozeznania: „Kto bowiem spożywa i pije, nie zważając na Ciało [Pańskie], wyrok sobie spożywa i pije" (1 Kor 11,27). Pojęcie to określa również zdolność rozeznania (odnalezienia prawdy) w sprawach innych ludzi: „Bo czyż nie znajdzie się wśród was ktoś na tyle mądry, by mógł rozstrzygać spory między swymi braćmi?" (1 Kor 6,5) ${ }^{31}$.

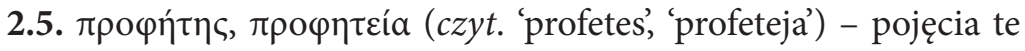
mają odpowiednio znaczenie "prorok”"32 oraz „prorokowanie”, ", dar prorokowania”34. Występują w NT 163 razy. Jedynie osoba posiadająca

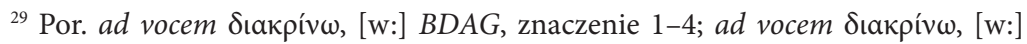

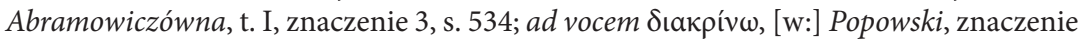
I.2.b, s. 129.

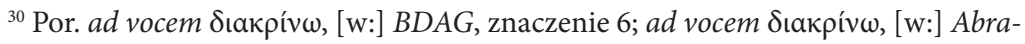

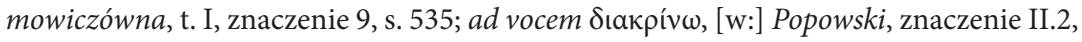
s. 129.

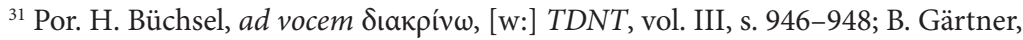

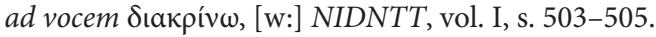

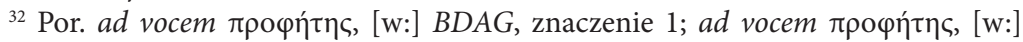

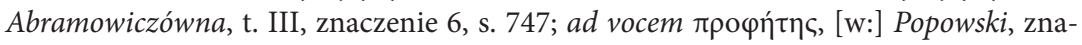
czenie 2 i 5, s. 537.

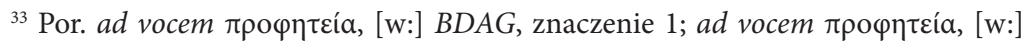

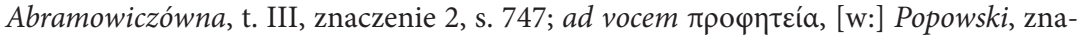
czenie 1, s. 537.

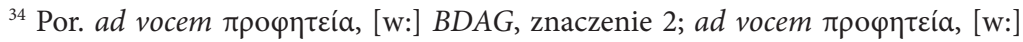

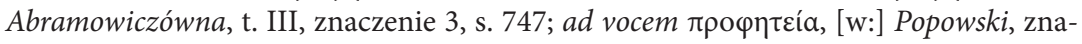
czenie 2, s. 537. 
ducha czy też dar prorokowania może dokonać odpowiedniego rozeznania i zdecydować, czy „słowo” lub „wola” pochodzi od Boga, czy nie: „innemu proroctwo, innemu rozpoznawanie duchów” (1 Kor 12,10). W takim przypadku można więc rozpoznać fałszywego proroka. Zadanie to jednak spoczywa na innych prorokach: „Prorocy niech przemawiaja po dwóch albo po trzech, a inni niech to roztrząsaja" [tutaj

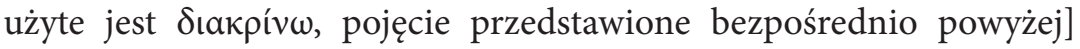
(1 Kor 14,29). Gdy ustaje charyzmat rozeznania, wtedy podstawą rozeznania duchów pozostaje poprawne wyznanie wiary: „Po tym poznajecie Ducha Bożego: każdy duch, który uznaje, że Jezus Chrystus przyszedł $w$ ciele, jest $z$ Boga. Żaden zaś duch, który nie uznaje Jezusa, nie jest $z$ Boga" $(1 \mathrm{~J} \mathrm{4}, 2-3)^{35}$. Rozeznanie jest dokonywane przez proroków dla Kościoła, wspólnoty.

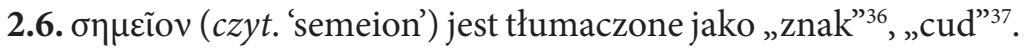
Pojęcie to występuje 77 razy w NT. W interesującym nas kontekście charakterystyczne są dwa ujęcia.

Pierwsze z nich dotyczy Ewangelii Jana i odnosi się do znaków „widzialnych” lub możliwych do zaobserwowania i powiązanych z Jezusem, a największym z nich było Jego Zmartwychwstanie. Znaki pomagają / pozwalają rozeznać Jezusa jako Syna Bożego posłanego przez Ojca: „Odpowiedziat mu Jezus: "Filipie, tak długo jestem $z$ wami, a jeszcze Mnie nie poznałeś? Kto Mnie widzi, widzi także i Ojca. Dlaczego więc mówisz: 'Pokaż nam Ojca?'»" (J 14,9). Znakiem tutaj jest sama osoba Jezusa i zdziałane przez Niego znaki, znane osobiście Filipowi ${ }^{38}$. Sam

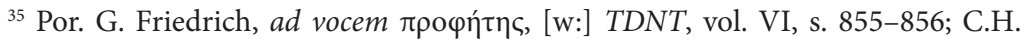

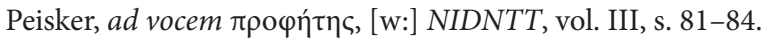

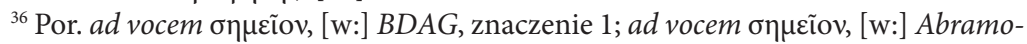

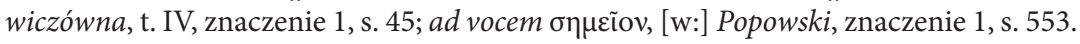

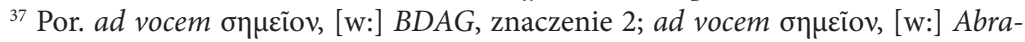

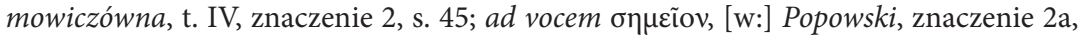
s. 553.

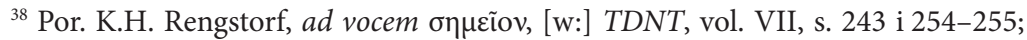

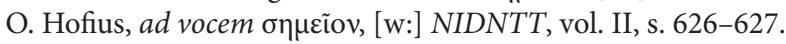


Jezus jest także znakiem koniecznym do rozeznania, choć niektórzy takiego znaku przyjąć nie chcą: „To plemię jest plemieniem przewrotnym. Żąda znaku, ale żaden znak nie będzie mu dany, prócz znaku Jonasza" (Łk 12,39; por. także Mk 8,12; Mt 16,4). Będzie On także ostatnim znakiem przed końcem czasów: „Wówczas ukaże się na niebie znak Syna Człowieczego" (Mt 24,30) ${ }^{39}$.

Drugie z nich, choć rzadko używane, dotyczy Listów św. Pawła i pośród różnych znaczeń dwa wychodzą na pierwszy plan. Pierwsze dotyczy „znaku obrzezania” dającego prawną możliwość rozeznania przynależności osoby do Narodu Wybranego, choć przez Pawła postrzeganego w świetle łaski zbawienia otrzymanego przez Jezusa raczej jako element formalny: „I (Abraham) otrzymał znak obrzezania jako pieczęć usprawiedliwienia osiagniętego dzięki wierze, która miał wtedy, gdy jeszcze nie był obrzezany. I tak stał się ojcem wszystkich tych, którzy nie mając obrzezania, wierza, by również im poczytano to za tytuł do usprawiedliwienia" $(\mathrm{Rz} 4,11)^{40}$. Kolejnym są znaki towarzyszące działalności Pawła i pozwalające rozeznać w nim prawdziwego Apostoła

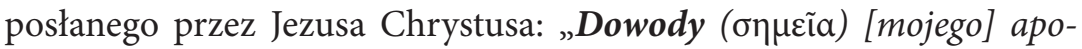
stolstwa okazaly się pośród was przez wielka cierpliwość, a także przez

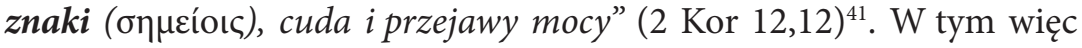
przypadku znaki te służyły innym, nie zaś Pawłowi.

2.7. $\tau \varepsilon ́ \lambda \varepsilon ı$ (czyt. 'teleios') ma znaczenie „doskonały”, „perfekcyjny” ${ }^{42}$, „dorosły”43. Pojawia się 19 razy w NT. Jego powiązanie z „,rozeznaniem” polega na fakcie, że jedynie „doskonali”, czyli ci, którzy osią-

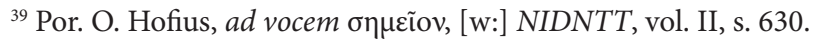

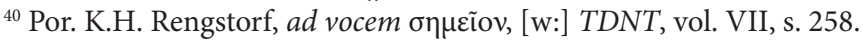

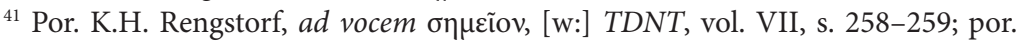

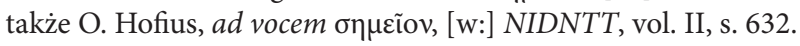

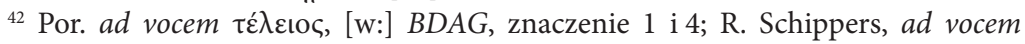

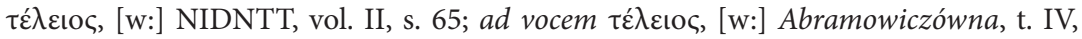

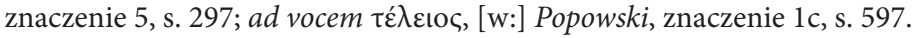

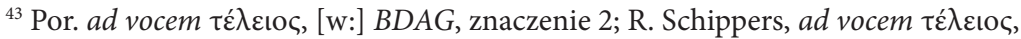

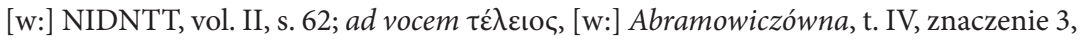

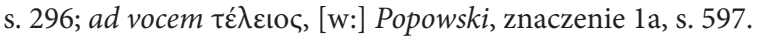


gnęli duchową dojrzałość, są zdolni do posługiwania się moralnym rozeznaniem dobrego i złego. Jest to główna różnica pomiędzy „dojrzałymi” a tymi, którzy są na początku rozwoju duchowego: „Przeciwnie, stały pokarm jest właściwy dla dorostych, którzy przez ćwiczenie maja władze umysłu zaprawione do rozróżniania dobra i zła" (Hbr 5,14) ${ }^{44}$. Mając na uwadze, że termin ten w LXX odnosił się do pojęcia wyrażającego „kompletność”, „integralność”, „doskonałość”, „nieskazitelność” (np. Rdz 6,9: „Noe, człowiek prawy, wyróżniał się nieskazitelnościa wśród współczesnych sobie ludzi; w przyjaźni z Bogiem żył Noe"), należy podkreślić, że „rozeznanie” jest wobec tego cechq ludzi dojrzałych duchowo $^{45}$.

\section{Podmiot rozeznania}

\section{Bóg}

Warunkiem umożliwiającym rozeznanie jest istnienie, życie. Ponieważ Bóg jest i żyje, możliwe jest dla Niego rozeznanie. To spostrzeżenie jest o tyle istotne, że w przypadku bóstw i domniemanych bogów Biblia daje ważną wskazówkę niemożności dokonania przez nich rozeznania: „Ich bożki - to srebro i złoto, robota rąk ludzkich. Maja usta, ale nie mówia; oczy maja, ale nie widza. Maja uszy, ale nie stysza; nozdrza maja, ale nie czują zapachu. Mają ręce, lecz nie dotykają; nogi maja, ale nie chodza; z gardła swego nie wydobęda głosu. Do nich sa podobni ci, którzy je robia, i każdy, kto im ufa" (Ps 115,4-8; por. także Ps 135,15-18). Obrazowo przedstawiono tutaj brak życia w bóstwach, a tym samym brak istnienia takich bóstw i w konsekwencji niemożność u nich i ich wyznawców rozeznania. W NT, w wyznaniu św. Piotra złożonym przy wielu skalnych grotach i rzeźbach bóstw pogańskich w Cezarei Filipowej, spotykamy się z określeniem: „Ty jesteś Mesjasz, Syn Boga żywego” (Mt 16,16).

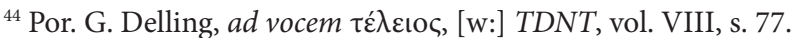

${ }^{45}$ Por. R. Schippers, ad vocem $\tau \dot{\lambda} \lambda \varepsilon ı$, [w:] NIDNTT, vol. II, s. 60.
} 
W przypadku Boga pierwszą wiadomość o Jego zdolności rozeznania znajdujemy już w Rdz 1,4: „Bóg, widząc, że światłość jest dobra, oddzielił ją od ciemności”. Należy więc podkreślić, że w przypadku Boga od samego początku akt stwórczy oceniany / rozeznany przez samego Stwórcę jest jako dobry (por. Rdz 1,10.12.18.21.25.31) i za każdym razem oceniany na podstawie tego, że Bóg widzi. Potrafi też dostrzec / rozeznać zło: „Gdy Bóg widziat, iż ziemia jest skażona, że wszyscy ludzie postępują na ziemi niegodziwie...” (Rdz 6,12). Można więc do zestawu przedstawionych wcześniej pojęć dodać jeszcze „widzieć” (רָָָ [czyt. 'raa']/ ó ó́w [czyt. 'horao']) w odniesieniu do sposobu rozeznania Boga. Nowy Testament kontynuuje tę myśl, np.: „Ojciec twój, który widzi w ukryciu, odda tobie" (Mt 6,4.6.18). Ap 10,6 ukazuje Stwórcę wieczne istniejącego: "przysiagł na Żyjącego na wieki wieków, który stworzył niebo i to, co $w$ nim jest".

Mając na uwadze efekt, do którego prowadzi rozeznanie, u Boga jest on wskazany przez najbardziej oczywiste stwierdzenie: „Bóg wie”. Przykładów potwierdzających to spostrzeżenie jest wiele i zostały wyrażone zaprezentowanym wcześniej czasownikiem יָּ (czyt. 'jada'), przykładowo mając zawsze jako podmiot poznawczy Boga: „Ty wiesz, kiedy siadam i wstaje. $Z$ daleka przenikasz moje zamysty" (Ps 139,2; por. także Ps 94,11). Podobnie o takiej wiedzy Boga świadczy Nowy Testament, np.: „Ojciec wasz wie, że tego potrzebujecie” (Łk 12,30).

\section{Człowiek}

Oddający cześć bóstwom wykonanym rękami ludzkimi ich twórcy są im podobni, tzn. również nie posiadają rozeznania: „[Tacy] nie mają świadomości ani zrozumienia, gdyż [mgła] przesłonięte sa ich oczy, tak iz nie widza, i serca ich, tak iż nie rozumieją. Taki się nie zastanawia; nie ma wiedzy ani zrozumienia, żeby sobie powiedzieć: Jedna połowę spaliłem $w$ ogniu, nawet chleb upiekłem na rozżarzonych węglach, $i$ upiekłem mięso, które zjadam, a z reszty zrobię rzecz obrzydliwą. Będę oddawat 
pokłon kawałkowi drewna" (Iz 44,18-19). Mamy więc tutaj do czynienia $\mathrm{z}$ biblijnym pojęciem możliwości braku rozeznania pośród ludzi.

Brak rozeznania kwalifikuje ludzi jako złych i jest zarazem znakiem degradacji: „Człowiek, co $w$ dostatku żyje, ale się nie zastanawia, przyrównany jest do bydląt, które gina (Ps 49,21). Efektem takiego odrzucenia rozeznania jest niemożność poznania sprawiedliwości: „Źli ludzie nie rozumieja sprawiedliwości, a szukajacy Pana pojmuja wszystko" (Prz 28,5; por. także Mdr 4,9).

Pierwszym zaś etapem rozeznania obecności lub działania Boga jest przyjęcie Jego własnego objawienia, np.: „poznacie, że Ja jestem Pan, gdy was wprowadze na ziemię izraelskq" (Ez 20,42; por. także Ez 6,13; Wj 7,5; $1 \mathrm{Krl}$ 20,13; Ps 46,10; Iz 43,10; Jr 24,7) ${ }^{46}$. Takie rozeznanie może dokonać się także wbrew woli człowieka: „Wtedy okażę potęgę moja nad faraonem i nad calym jego wojskiem. Poznaja wówczas Egipcjanie, że Ja jestem Pan" (Wj 14,4). Gdy jednak człowiek podejmuje wysiłek rozeznania działalności Boga, On sam wspiera taki wysiłek: „Kim jest człowiek, co się boi Pana? Takiemu On wskazuje, jaka droge wybrać” (Ps 25,12; por. także prośbę Salomona o mądrość w Mdr 9,4.9 i pochodzenie mądrości od Boga w Syr 1,1 i Da 2,20) ${ }^{47}$.

Rozeznanie jest wskazywane jako pożądane i jest oznaką dojrzałości: „Jakże starcom przystoi mądrość, a szanowanym rozeznanie

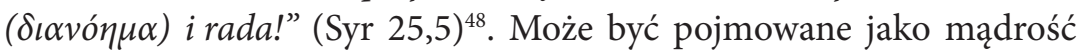
i jako taka jest darem Boga: „W sercu rozumnego spoczywa mądrośc” (Prz 14,33) oraz „Bo człowiekowi, który Mu jest miły, daje On mądrość i wiedzę" (Koh 2,26).

Dzięki pomocy innych można nabyć rozeznanie, i wymownym przykładem jest tutaj poznawanie Prawa Bożego: „Czytano więc $z$ tej księgi, księgi Prawa Bożego, dobitnie, zdodaniem objaśnienia, tak

${ }^{46}$ Por. G.J. Botterweck, ad vocem vocem ירָע [w: [w:] NIDOTTE, vol. II, s. 402-405.

${ }^{47}$ Por. H. Ringgren, ad vocem בין, [w:] TDOT, vol. II, s. 101-102; T.E. Fretheim, ad בין [w:] NIDOTTE, vol. I, s. 642.

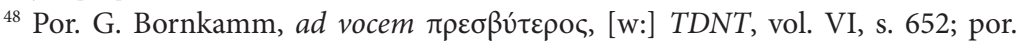

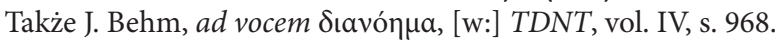


że lud rozumial czytanie" (Ne 8,8). Nowy Testament podkreśla tutaj wsparcie modlitewne innych dla osiągnięcia celu: „nie przestajemy za was się modlić i prosić [Boga], abyście - przez cała mądrość i duchowe

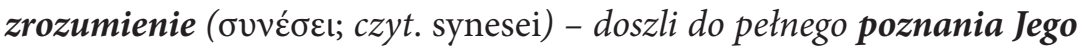
woli" (Kol 1,9).

Generalnie zadanie pomocy w rozeznaniu woli Bożej spoczywało na prorokach, narzędziem zaś było upomnienie, np.: „Jeśli jednak upomnisz sprawiedliwego, by sprawiedliwy nie grzeszyt, i jeśli nie popelni grzechu, to z pewnościa pozostanie przy życiu, ponieważ przyjąt upomnienie, ty zaś ocalisz samego siebie" (Ez 3,31). Kolejnym narzędziem było badanie postępowania moralnego Ludu: „Ustanowiłem cię badaczem mego ludu, byś poznat i zbadat jego postępowanie" (Jr 6,27). Metaforycznie samo rozeznanie woła o skierowanie uwagi na zakryte znaczenie rzeczy, by móc dokonać poprawniejszego wyboru: „Czy Mqdrość nie nawołuje? Nie wysila głosu Roztropnośc?” (Prz 8,1).

Człowiek obdarzony rozeznaniem potrafi zdobyć wiedzę z zachowania innych: „Gdy jednak Dawid zauważyl, że słudzy jego rozmawiaja szeptem, zrozumiat, że dziecko zmarto" (2 Sm 12,19).

$\mathrm{Z}$ dotychczasowej prezentacji należy podkreślić, że rozeznanie dotyczy tak pojedynczych osób jak i grup czy narodów.

\section{Przedmiot rozeznania}

\section{Dobro - zło}

Pierwszą wzmianką o rozeznaniu jest sugestia węża w ogrodzie rajskim, że człowiek jest w stanie poznać dobro i zło. W obu językach רע iט טוֹב i wyrażone przymiotnikami urzeczownikowionymi 'tow')

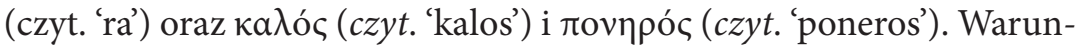
kiem miało być złamanie zakazu spożywania owocu z drzewa wskazanego przez Boga: „Ale wie Bóg, że gdy spożyjecie owoc $z$ tego drzewa, otworza się wam oczy i tak jak Bóg będziecie znali dobro i zło" ( $\operatorname{Rdz} 3,5$; por. także $\mathrm{Rdz} 2$,9.17; Rdz 3,22). Przewrotne jednak w kuszeniu jest to, 
że na ówczesną chwilę nie było w ogrodzie żadnego zła, gdyż Bóg stworzył wszystko wyłącznie jako dobre. Obrazowo rzecz ujmując, pierwszym narzędziem rozeznania pomiędzy dobrem a złem było drzewo. Podkreślić jednak należy, że jego Stwórcą był Bóg, więc to On jest źródłem rozeznania („Napetnit ich wiedza i rozumem, o złu i dobru ich pouczyl"; Syr 17,7 ${ }^{49}$. Człowiek w raju widział Boga i rozmawiał z Nim, czyli znał Boga i odróżniał Go od stworzeń. Oznacza to więc, że wbrew pierwotnej pokusie szatańskiej człowiek posiadał już dar rozeznania, choć dotyczył on jedynie dobra. Dlatego rozróżniwszy dobro od zła („stały pokarm jest właściwy dla dorosłych, którzy przez ćwiczenie maja władze umysłu zaprawione do rozróżniania dobra i zła"; Hbr 5,14) należy wybierać tylko dobro: „Miejcie wstręt do złego, podążajcie za dobrem” (Rz 12,9; por. także 1 P 3,11; 3 J 11) ${ }^{50}$. Ponieważ trudności z wyborem w raju nie było, grzech jest więc przyczyną trudności w rozeznaniu.

\section{Duchy}

Rozeznanie tego typu odbywa się na poziomie duchowym, czyli na poziomie ubogaconym łaską Bożą i tutaj wskazówką jest myśl św. Pawła: „Człowiek zmysłowy bowiem nie pojmuje tego, co jest z Bożego Ducha. Gtupstwem mu się to wydaje i nie może tego pojąć, bo tylko Duchem można to zrozumieć" (1 Kor 2,14). Mając na myśli jednak rozeznanie duchów, odnosimy się do podmiotu czynności, czyli duchów oraz stanów ducha, czyli efektów ich działania w człowieku. Narzędziem pomocnym w takim zadaniu jest wiara, którą otrzymujemy jako dar Boży: „aby wiara wasza opierała się nie na mądrości ludzkiej, lecz na mocy Bożej" (1 Kor 2,5). Zadanie zaś rozeznawania duchów jest obowiązkiem, który pomaga wykluczyć oszustwo i podaje się także ważną wskazówkę dla rozeznania: „Umiłowani, nie każdemu duchowi dowierzajcie, ale badajcie duchy, czy są z Boga, gdyż wielu fałszywych proroków pojawiło się

${ }^{49}$ Por. I. Höver-Johag, ad vocem בiv, [w:] TDOT, vol. V, s. 308-311; R.P. Gordon, ad vocem טוֹט, [w:] NIDOTTE, vol. II, s. 347-348.

${ }^{50}$ Por. W. Grundmann, ad vocem ka入ós, [w:] TDNT, vol. III, s. 545-550; E. Beyreuther, ad vocem кa入óc, [w:] NIDNTT, vol. II, s. 104-105. 
na świecie. Po tym poznajecie Ducha Bożego: każdy duch, który uznaje, $\dot{z} e$ Jezus Chrystus przyszed $t w$ ciele, jest $z$ Boga" (1 J 4,1-2). Mocą wiary więc należy odrzucić rozeznane złe duchy ${ }^{51}$. Konieczność zaś rozeznania duchów wynika $\mathrm{z}$ troski o zbawienie.

\section{Prawda - fałsz}

Fundamentem tego rozeznania jest fakt, że Bóg mówi słowa prawdziwe, stąd człowiek powinien postępować podobnie: „Podstawa Twego słowa jest prawda, i wieczny jest każdy Twój wyrok sprawiedliwy"

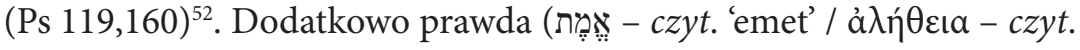
'aletheja') posiada moc wyzwolenia, stąd konieczność jej poznania: „Jeżeli trwacie w nauce mojej, jesteście prawdziwie moimi uczniami i poznacie prawde, a prawda was wyzwoli" (J 8,31-32). Rozeznanie prawdy prowadzi także do uznania w wierze Prawdy Osobowej oraz daje dostęp do Boga Ojca: „Odpowiedział mu Jezus: "Ja jestem droga i prawda, i życiem. Nikt nie przychodzi do Ojca inaczej jak tylko przeze Mnie»" (J 14,6). A takich właśnie czcicieli Bóg szuka: „prawdziwi czciciele będa oddawać cześć Ojcu w Duchu i prawdzie, a takich to czcicieli szuka Ojciec" $(\mathrm{J} 4,23)^{53}$. Natomiast zamiana prawdy na kłamstwo doprowadza do ruiny spowodowanej bałwochwalstwem: „Prawdę Bożą przemienili oni w kłamstwo i stworzeniu oddawali cześć, i służyli jemu, zamiast służyć Stwórcy, który jest błogosławiony na wieki” $(\mathrm{Rz} 1,25)^{54}$.

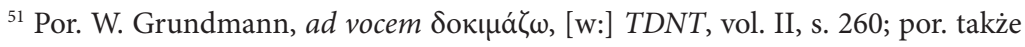

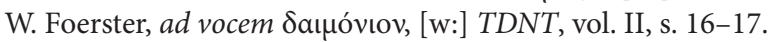

${ }^{52}$ Por. G. Quell, ad vocem à $\lambda \hat{\theta} \theta \varepsilon ı$, [w:] TDNT, vol. I, s. 235-236; A.C. Thiselton, ad vocem à $\lambda \hat{\theta} \theta \varepsilon ı$, [w:] NIDNTT, vol. III, s. 883-894; A. Jepsen, ad vocem אֶֶֶ, [w:] TDOT, vol. I, s. 303-307.

${ }^{53}$ Por. R. Bultmann, ad vocem à $\lambda \hat{\theta} \theta \varepsilon ı$, [w:] TDNT, vol. I, s. 246.

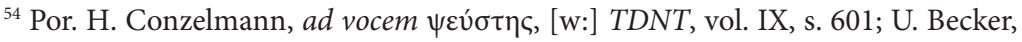

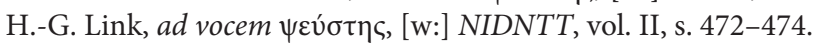




\section{Wola Boża}

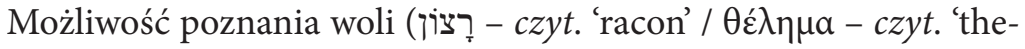
lema’) Bożej staje się źródłem radości człowieka: „Jest moją radością, mój Boże, czynić Twoja wolę, a Prawo Twoje mieszka w moim wnętrzu" (Ps 40,9). Chrystus zna wolę Ojca, dlatego ją wypełnia (J 4,34). Podstawą rozeznawania woli Bożej jest uznanie faktu, że Bóg stworzył wszystko swą wolą: „bo Ty stworzyłeś wszystko, a $z$ woli Twojej istniało [to] i zostało stworzone" (Ap 4,11). Rozeznanie zaś woli Bożej przez ludzi jest zgodne z zamysłem Bożym: „przemieniajcie się przez odnawianie umysłu, abyście umieli rozpoznać, jaka jest wola Boża: co jest dobre, co Bogu miłe i co doskonate" (Rz 12,2) ${ }^{55}$. To zadanie jest tak istotne, że stało się treścią modlitwy, której Jezus nauczył Apostołów: „niech Twoja wola się spetnia na ziemi, tak jak w niebie" (Mt 6,10).

\section{Mądrość}

Jest ona darem Boga i pomaga rozeznawać oraz wybierać życie zgodne z Prawem Bożym: „Ukazałem ci drogę mądrości, naprowadziłem na ścieżki prawości" (Prz 4,11). Dzięki posiadanej mądrości (חָכְָָ - czyt. 'chochma'/ бoфía - czyt. 'sofija') nabywa się zdolności rozróżniania dobra i zła oraz praktykowania dobra: „oto spełniam twoje pragnienie i daje ci serce mądre i pojętne” (1 Krl 3,12). Mądrości należy nie tylko szukać, ale znalazłszy ją, trzeba być jej posłusznym: „ku mądrości nachylisz swe ucho, ku roztropności skłonisz swe serce” (Prz 2,2). Strzeżenie mądrości zawartej w Prawie gwarantuje zachowanie zdolności rozeznawania: „Strzeżcie ich $i$ wypełniajcie je, bo one sq wasza mądrością i umiejętnością w oczach narodów" (Pwt 4,4) ${ }^{56}$. Obserwujący

${ }^{55}$ Por. G. Schrenk, ad vocem $\theta \varepsilon ́ \lambda \eta \mu a$, [w:] TDNT, vol. III, s. 55-59; D. Müller, ad vocem $\theta \dot{\varepsilon} \lambda \eta \mu \alpha$, [w:] NIDNTT, vol. III, s. 1020-1022; H.M. Barstad, ad vocem רฺָּ, [w:] TDOT, vol. XIII, s. 625-628; T.E. Fretheim, ad vocem רָּוֹ [w:] NIDOTTE, vol. III, s. 183.

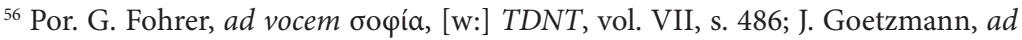

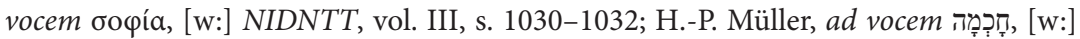
TDOT, vol. IV, s. 379-381; G.H. Wilson, ad vocem חָכְָָָה, [w:] NIDOTTE, vol. II, s. 128130. 
działalność Jezusa zastanawiali się nad pochodzeniem Jego mądrości (choć strona bierna czasownika greckiego jednoznacznie wskazuje na jej Boskie pochodzenie), musieli jednak wykazać się rozeznaniem ukazywanych znaków, co z kolei zakładało ich własną mądrość: „Skąd to u Niego? I co to za madrość, która Mu jest dana? I takie cuda dzieja się przez Jego ręce" (Mk 6,2). Dar mądrości jest udzielony wierzącym z postanowienia Bożej woli i za pośrednictwem Chrystusa właśnie w celu rozeznawania działania Bożego: „według bogactwa Jego łaski. Szczodrze ja na nas wylał w postaci wszelkiej mądrości i zrozumienia" (Ef 1,7-8; por. także Jk 1,5) ${ }^{57}$. Mądrość jest narzędziem, a także efektem właściwego rozeznania: „Kto spośród was jest mądry i rozsądny? Niech wykaże się $w$ swoim nienagannym postępowaniu uczynkami spetnianymi $z$ łagodnościa właściwa madrości” (Jk 3,13).

\section{Powołanie}

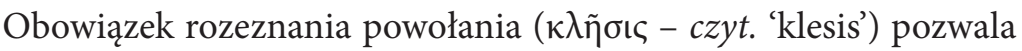
ustalić jego źródło: „Przeto przypatrzcie się, bracia, powołaniu waszemu! Według oceny ludzkiej niewielu [tam] mędrców, niewielu możnych, niewielu szlachetnie urodzonych" (1 Kor 1,26). Po dokonaniu rozeznania powołania istotna staje się wytrwałość w nim, gdyż jako takie jest ono darem: „Zachęcam was zatem ja, więzień w Panu, abyście postępowali w sposób godny powołania, do jakiego zostaliście wezwani" (Ef 4,1; por. także 1 Tes 1,11). Powołanie do świętości jest odwieczne i dokonane w Chrystusie, a jego zapowiedzią było dokonane zbawienie: „On nas wybawił i wezwał świętym powołaniem nie na podstawie naszych czynów, lecz stosownie do własnego postanowienia i łaski, która nam dana została w Chrystusie Jezusie przed wiecznymi czasami" (2 Tm 1,9). Jest więc ono powołaniem wspólnoty odkupionych ${ }^{58}$. Warto wspomnieć także powołania i ich rozeznanie w czasach Starego Testamentu, wska-

${ }^{57}$ Por. U. Wilckens, ad vocem бoфía, [w:] TDNT, vol. VII, s. 514-523.

${ }^{58}$ Por. K.L. Schmidt, ad vocem $\kappa \lambda \tilde{\eta} \sigma ı \varsigma$, [w:] TDNT, vol. III, s. 491-492; L. Coenen, ad vocem $\kappa \lambda \tilde{\eta} \sigma \iota$, , [w:] NIDNTT, vol. I, s. 273-275. 
zując choćby powołania partykularne do bycia prorokiem. Tutaj wyraźnym przykładem jest powołanie młodego Samuela (1 Sm 3,1-9), które pomagał mu odkryć kapłan Heli. Innym przykładem jest powołanie Jeremiasza (Jr 1,4-9), gdzie Bóg sam bezpośrednio wyjawia swój plan prorokowi.

\section{Pochodzenie darów}

W tym przypadku pragnę podkreślić dary ( $\delta \tilde{\omega} \rho o v-c z y t$. 'doron') pochodzące od Boga. Największym z nich oczywiście jest zbawienie, będące wyrazem Bożej łaskawości: „Łaska bowiem jesteście zbawieni przez wiare. A to pochodzi nie od was, lecz jest darem Boga" (Ef 2,8). Oczywiście należy podkreślić dar Osoby Ducha Świętego ofiarowanego po zmartwychwstaniu Chrystusa wierzącym bez względu na ich pochodzenie: „Izdumieli się wierni pochodzenia żydowskiego, którzy przybyli z Piotrem, że dar Ducha Świętego wylany został także na pogan" (Dz 10,45). Dary Boże są liczne i często jako dawca wskazywany jest Chrystus: „o ileż obficiej spłynęła na nich wszystkich łaska i dar Boży, łaskawie udzielony przez jednego Człowieka, Jezusa Chrystusa" (Rz 5,15). Każdy też otrzymuje odpowiedni dar / dary według planu i woli Bożej: „Każdemu zaś z nas została dana łaska wedtug miary daru Chrystusowego" (Ef 4,7) ${ }^{59}$. Rozeznanie darów (charyzmatów) i ich pochodzenia pomaga w skierowaniu się ku ich źródłu: „Różne sq dary łaski, lecz ten sam Duch" (1 Kor 12,4). Ich wielorakość została przedstawiona w 1 Kor 12,8-10 i choć ma ona znamiona listy, nie wyczerpuje Bożych darów. Modelem zaś użytym do przedstawienia ich liczności, różnorodności i funkcji jest ciało i jego członki (1 Kor 12,12-27). Mają one wszystkie służyć jedności i wzrostowi ciała ${ }^{60}$.

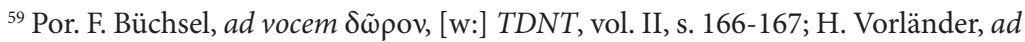
vocem $\delta \tilde{\omega} \rho o v$, [w:] NIDNTT, vol. II, s. 41-42.

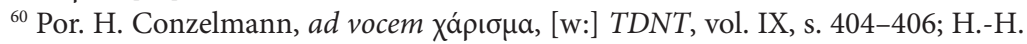

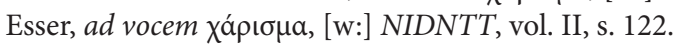




\section{Szaleństwo}

Rozeznanie szaleństwa (אְְִּ - czyt. 'iwelet') jest łatwe dla Boga, gdyż On je widzi: „Boże, Ty znasz moja głupotę [szaleństwo] i występki moje nie sa zakryte przed Tobq" (Ps 69,6). Efektem szaleństwa są nawet rany i potrzeba daru rozeznania, by sobie uświadomić ich prawdziwą przyczynę: „Cuchna, ropieją me rany na skutek mego szaleństwa” (Ps 38,6). Brak rozeznania poprzez szaleństwo doprowadził do bałwochwalstwa: „Także wśród proroków Samarii widziałem szaleństwo: prorokowali w imię Baala i zwodzili mój naród, Izraela" (Jr 23,13). Łatwo jest człowiekowi prawemu rozeznać mądrego od głupca: „Język madrych ocieka wiedza, usta zarozumialca [głupca] wyrażaja głupotę [szaleństwo]" (Prz 15,2). Unikanie szaleństwa oraz jego rozeznanie pozwala poznać Bożą sprawiedliwośćc1. W Nowym Testamencie pojęcie to

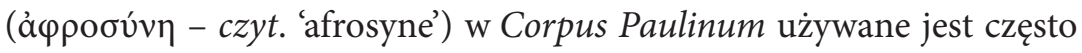
$\mathrm{w}$ sensie autoironicznym lub hiperbolicznym. U synoptyków jest pojęciem wybranym przez Jezusa na określenie faryzeuszów przy okazji ich pytania o czystość rytualną: „Nierozumni! Czyż Stwórca zewnętrznej strony nie uczynił także wnętrza?” (Łk 11,40). Ostrzeżenie ze strony Jezusa przed takim postępowaniem ma skutkować opamiętaniem: „Lecz Bóg rzekł do niego: "Głupcze, jeszcze tej nocy zażadaja twojej duszy od ciebie; komu więc przypadnie to, coś przygotował?»" (Łk 12,20) ${ }^{62}$. Nieumiejętność rozeznania woli Bożej określana jest w końcu jako brak rozsądku: „Nie bądźcie przeto nierozsądni, lecz usiłujcie zrozumieć, co jest wola Pana” (Ef 5,17). Ponieważ pojęcie ä $\varphi \rho \omega v$ (czyt. 'afron') posiada najpierw znaczenie "pozbawiony świadomości”, „nieżywy”, staje się zrozumiałe, dlaczego szaleństwa należy unikać.

${ }^{61}$ Por. H. Cazelles, ad vocem אְִּּ, [w:] TDOT, vol. I, s. 139-140; P. Chou-Wee, ad vocem אְִּּ, [w:] NIDOTTE, vol. I, s. 304-305.

${ }^{62}$ Por. G. Bertram, ad vocem ä $\varphi \rho \omega v$, [w:] TDNT, vol. IX, s. 230-232; J. Goetzmann, ad vocem ä $\varphi \rho \omega v$, [w:] NIDNTT, vol. III, s. 1025-1026.

${ }^{63}$ Por. ad vocem ä $\varphi \rho \omega v$, [w:] Abramowiczówna, t. I, s. 397. 


\section{Narzędzie / ośrodek rozeznania}

\section{Serce}

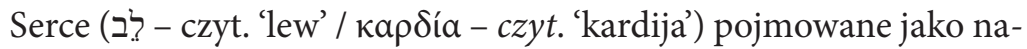
rzędzie myślenia i osądzania jest najpierw darem Boga: „Nie dał wam Pan aż do dziś dnia serca, które by rozumiało” (Pwt 29,3). Jest ono siedliskiem myśli, nawet jeśli ich rozeznanie nie jest proste i potrzebna jest pomoc zewnętrzna: „tajemnica ta stała mi się wiadoma nie dlatego, jakobym był mędrszy od wszystkich ludzi, lecz aby udzielić wyjaśnienia królowi i żebyś rozumiał myśli swego serca" (Dn 2,30). W sercu mogą przebywać złe myśli i bez względu na to, czy zostaną ujawnione, czy nie, mają zły wpływ na człowieka: „Ich oko wystaje z tłuszczu, złe zamysły nurtuja ich serca” (Ps 73,7). Również serce Boga posiada swoje plany: „Nie ustanie gniew Pana, dopóki nie wykona On i nie urzeczywistni zamysłów swego serca" (Jr 23,20). Bóg może skłonić serce człowieka do dobrych wyborów i czynów: „Nakłoń me serce do Twoich napomnień, a nie do zysku!" (Ps 119,36). Odrzucenie zaś tego, co rozeznane jako grzech, związane jest ze zmianą dotychczasowego sposobu życia, czyli zmianą serca: „Odrzućcie od siebie wszystkie grzechy, które popetnialiście przeciwko Mnie, i uczyńcie sobie nowe serce i nowego ducha" (Ez 18,31). Bóg w końcu może napełnić serce bojaźnią, co jest podstawą wierności człowieka: „Napełnię ich serca moja bojaźnia, by się już nie odwracali ode Mnie" (Jr 32,40) ${ }^{64}$. W ten sposób bojaźń Boża w sercu jest podstawą właściwego rozeznania. W przeciwnym przypadku serce zatwardziałe odrzuca pełnienie woli Boga: „Mimo to serce faraona pozostało uparte i nie ustuchat ich, jak zapowiedział Pan" (Wj 7,13). Nowy Testament rozumie serce bardzo podobnie. Gości ono uczucia, emocje, pragnienia i pasje, stąd posiada wpływ na efekt rozeznania, np.: „Niech się nie trwoży serce wasze ani się lęka" (J 14,27; por. J 14,1; Mk 11,23). Po do-

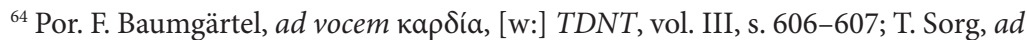

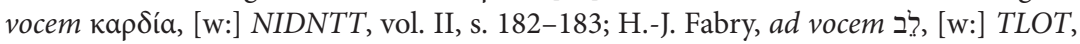
vol. VII, s. 414-425. 
konaniu rozeznania serce może nakazać odpowiednie działanie, stając się tym samym ośrodkiem woli: „Każdy niech przeto postapi tak, jak mu nakazuje jego własne serce" (2 Kor 9,7; por. także Łk 21,14). Ale serce, nawet po dokonaniu właściwego rozeznania, może trwać w złym wyborze: „Z wnętrza bowiem, z serca ludzkiego pochodza złe myśli, nierzad, kradzieże, zabójstwa, cudzołóstwa, chciwość, przewrotność, podstęp, wyuzdanie, zazdrość, obelgi, pycha, głupota" (Mk 7,21-22; por. także Rz 1,21). Szczerość zaś intencji rozeznawana i osądzana jest przez Słowo Boże: „Żywe bowiem jest słowo Boże (...), zdolne osądzić pragnienia i myśli serca" (Hbr 4,12; por. 1 Kor 4,5). W końcu serce może zostać opanowane przez szatana, stając się wówczas narzędziem zła: „Ananiaszu - powiedziat Piotr - dlaczego szatan zawładnąt twym sercem, że skłamałeś Duchowi Świętemu" (Dz 5,3) ${ }^{65}$.

\section{Nerki}

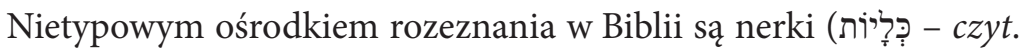

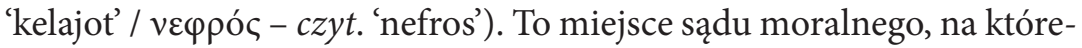
go podstawie mogą one upominać człowieka: „Błogosławię Pana, który dał mi rozsądek, bo nawet $w$ nocy upomina mnie serce_[język oryginalny używa tutaj słowa „nerki”] (Ps 16,7). Stwórcą tego ośrodka oceny moralnej jest Bóg: „Ty bowiem utworzyłeś moje nerki, Ty utkałeś mnie w tonie mej matki” (Ps 139,13). Nerki czynnie reagują na zło: „Gdy się trapiło moje serce, a w nerkach odczuwałem ból dotkliwy” (Ps 73,21). Choć są ukryte w człowieku, Bóg z łatwością widzi ich decyzje, sądy i rozeznania: „Panie Zastępów, Ty, który doświadczasz sprawiedliwego i który patrzysz na nerki i serce" (Jr 20,12; por. Jr 11,20; 17,10; Ps 7,10). Prawdopodobnie dlatego, że zadaniem nerek jest filtrowanie, czyli metonimicznie potrafią one dokonać właściwego sądu, dlatego tłuszcz z nerek uchodził za najcenniejszy w ofiarach całopalnych (por. szczególnie Pwt 32,14, gdzie w tłumaczeniu polskim brakuje jednak odniesienia do nerek; por. także Kpł 4,9; 7,4). Jedyne odniesienie do nerek w NT od-

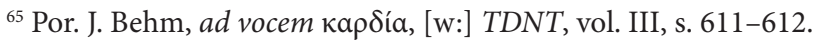


najdujemy w Ap 2,23: „A wszystkie Kościoły poznają, że Ja jestem Ten, co przenika nerki i serca; i dam każdemu $z$ was według waszych czynów". Pozostaje ono konceptualnie w tym samym kręgu, co ST ${ }^{66}$.

\section{Rozum}

Klasycznym ośrodkiem rozeznania i sądu jest rozum. W ST rolę tę pełni serce, nerki, dusza. Pośrednio rozum ukazywany jest jako efekt uzyskanego poznania. W przypadku NT pojęcie to prawie wyłącznie pojawia się w Corpus Paulinum - 21 razy (wyjątkami są Łk 24,45 i Ap 13,18; 17,9). Jego zadaniem jest „rozumienie”, czyli pojmowanie rzeczywistości: „Tu trzeba zrozumienia [dosł. rozumu], o majacy madrość!” (Ap 17,9). Do wykonania swej funkcji pojmowania tajemnic Pisma Świętego rozum może zostać wsparty łaską Chrystusa: „Wtedy oświecił ich umysty, aby rozumieli Pisma" (Łk 24,45). Choć nikt własnymi siłami nie jest w stanie poznać zamysłu (rozumu) Boga, to jednak może to wiązać się z otrzymanym darem rozeznania "rozumu” (= woli) Boga: „Któż więc poznał zamysł [dosł. rozum] Pana tak, by Go mógł pouczać? My właśnie znamy zamysł [dosł. rozum] Chrystusowy" (1 Kor $2,16)^{67}$. To staje się podstawą każdego następnego rozeznania.

\section{Sumienie}

Najbardziej oczywiste pojęcie powiązane z rozeznaniem w sensie moralnym to sumienie. W Biblii jednak występuje dość rzadko - 30 razy w NT. Stary Testament natomiast nie posiada pojęcia na określe-

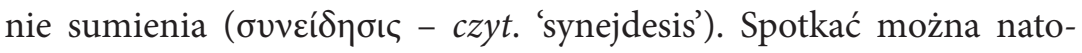
miast pojęcia określające, jak w przypadku rozumu, zadania sumienia: serce, nerki, dusza. Znajomość dobra i zła polega na pamiętaniu i zachowywaniu Bożych przykazań: „Jest moją radością, mój Boże, czynić

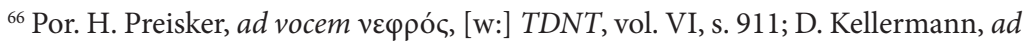

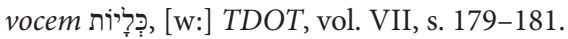

${ }^{67}$ Por. J. Behm, ad vocem voũc, [w:] TDNT, vol. IV, s. 958-959; G. Harder, ad vocem voṽc, [w:] NIDNTT, vol. III, s. 126-128. 
Twoja wole, a Prawo Twoje mieszka w moim wnętrzu” (Ps 40,9). Przeciwieństwem jest odrzucenie w swym sercu Boga i Jego praw: „Mówi głupi w swoim sercu: «Nie ma Boga»" (Ps 14,1; 53,2). Łatwo zauważyć, że sumienie pojmowane jest jako posłuszeństwo Bogu, czego wyrazem jest choćby: „A teraz, Izraelu, stuchaj praw i nakazów, które ucze was wypetniać, abyście żyli i doszli do posiadania ziemi, która wam daje Pan, Bóg waszych ojców" (Pwt 4,1; por. Pwt 5,1; a także fundamentalny w tej kwestii tekst Pwt 6,4n). Oznacza to, że elementem decydującym o dobru i złu, nawet na forum wewnętrznym, jest słowo Boga: „Pouczę cię i wskażę drogę, która pójdziesz; umocnię moje spojrzenie na tobie” (Ps $32,8)^{68}$. W NT zdecydowana większość wystąpień pojęcia znajduje się w Corpus Paulinum (20 na 30 w całości wystąpień). Najpierw podkreślmy jedność z rozumieniem sumienia w ST jako posłuszeństwa słowu Bożemu: „Wykazuja oni, że treść Prawa wypisana jest wich sercach, gdy jednocześnie ich sumienie staje jako świadek, a mianowicie ich myśli na przemian ich oskarżające lub uniewinniające" ( $\mathrm{Rz} 2,15$; por. także 2 Kor 1,12; 1 P 2,19). Sumienia innych ludzi są w stanie rozpoznać właściwe działanie Apostoła i wskazać na obiektywną i zgodną z wolą Bożą intencję czynu: „ukazywaniem prawdy poddajemy siebie samych w obliczu Boga osądowi sumienia każdego człowieka" (2 Kor 4,2). Odrzucając sąd sumienia, podejmuje się ryzyko zatracenia wiary samej i jej owoców w walce duchowej: „w myśl proroctw (...), byś [wsparty] nimi toczył dobra walkę, mając wiarę i dobre sumienie. Niektórzy, odrzuciwszy je, stali się rozbitkami w sprawach wiary" (1 Tm 1,18-19). W końcu sumienie pojmowane jest jako samoświadomość działającego człowieka odpowiedzialnego za swe czyny: „Chluba bowiem jest dla nas świadectwo naszego sumienia, bo w prostocie serca i szczerości wobec Boga, a nie według mądrości doczesnej, lecz według łaski Bożej postępowaliśmy na tym świecie, szczególnie względem was" (2 Kor 1,12) ${ }^{69}$.

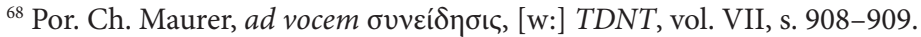

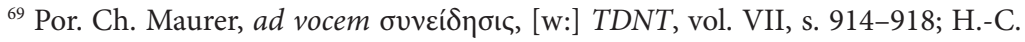

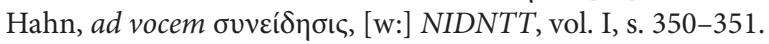




\section{Podsumowanie}

Tematyka rozeznania moralnego w Biblii prezentowana jest dość szeroko i na przestrzeni całego tekstu natchnionego. Zebrane w jednym miejscu elementy rozeznania dają wyraźny jego obraz, a bogata terminologia, od przestrzeni duchowej aż po materialną, ukazuje zaangażowanie całego człowieka w ten proces. Bóg i człowiek (przez Boga obdarzony zdolnością rozeznania) potrafią i oceniają rzeczywistość zewnętrzną i wewnętrzną. Wielość rozeznawanych przestrzeni dotyczy kwestii dotykających samego człowieka i jego relacji do Boga oraz innych ludzi. Narzędzia rozeznania, być może zadziwiające współczesnego człowieka, wskazują przede wszystkim na możliwość dokonania rozeznania i podejmowania na tej podstawie decyzji o wartości moralnej rozeznanego przedmiotu, a stąd do jego akceptacji lub odrzucenia. Możliwość zapoznania się z tymi elementami zebranymi w jednym miejscu ułatwia przyswojenie sobie złożonej tematyki rozeznania biblijnego.

\section{Summary}

The reality of discernment in the Bible is presented on a single level regarding the term itself and on a broader presentation level. This paper assumes the task of presenting the semitic-hellenistic mentality and of the cultural civilizations surrounding the homeland of the Bible. Exposition of the discerning subjects, God and man, helps to discover the dependence of man on divine gifts and his capacity to use such gifts for personal, as well as, the common good and also helps to build the relations of love and friendship with God and others. The objects of the discernment, i.e. the existential and moral dimensions of human life 
show on one side the necessary fields of discernment and on the other helps to discover useful help in such dimensions. The tools or the centers of the discernment help to make it effective and allow for upright moral choices. Systematization is what is new and through the numerous biblical quotation some kind of help is offered to the reader to apprehend and corroborate the knowledge about biblical discernment.

Keywords: terminology of discernment, subject of discernment, object of discernment, tools of discernment.

\section{Bibliografia}

\section{Źródła}

A Greek-English Lexicon of the New Testament and other Early Christian Literature. Based on Walter Bauer's Griechisch-Deutsches Wörterbuch zu den Schriften des Neuen Testaments und der früh christlichen Literatur, sixth edition; English editions by W.F. Arndt, F.W. Gingrich, F.W. Danker, London 2000 (skrót: BDAG).

A Hebrew and English Lexicon of the Old Testament, F. Brown, S.R. Driver, C.A. Briggs (eds.), Oxford 1907 (skrót: BDB).

Greek-English Lexicon of the New Testament, J.H. Thayer (ed.), Grand Rapids 1983.

New International Dictionary of Old Testament Theology and Exegesis, vol. I-V, W.A. Van Gemeren (General Editor), Grand Rapids 1997 (skrót: NIDOTTE).

Słownik grecko-polski, Z. Abramowiczówna, t. I-IV, Warszawa 1958-1965 (skrót: Abramowiczówna).

The Dictionary of Classical Hebrew, vol. I-VIII, D.J.A. Clines (ed.), Sheffield 1995 (skrót: $D C H$ ).

The Hebrew and Aramaic Lexicon of the Old Testament, vol. I-V, L. Koehler, W. Baumgartner (eds.), tr. M.E.J. Richardson (English Redaction), Leiden 1994 (skrót: HALOT). 
The New International Dictionary of the New Testament Theology, vol. I-III, Translated, with Additions and Revisions, from the German Theologisches Begriffslexikon zum Neuen Testament, edited by L. Coenen, E. Beyreuther, H. Bietenhard, C. Brown (English editor), Grand Rapids 1986 (skrót: NIDNTT).

Theological Dictionary of the New Testament, vol. I-X, G. Kittel, G. Friedrich (eds.), Grand Rapids 1991 (repr.) (skrót: TDNT).

Theological Dictionary of the Old Testament, vol. I-XV, G.J. Botterweck, H. Ringgren, H.-J. Fabry (eds.), Grand Rapids 1975 (skrót: TDOT).

Theological Lexicon of the Old Testament, vol. I-III, E. Jenni, C. Westermann (eds.), Peabody 1997 (skrót: TLOT).

Wielki Stownik Grecko-Polski Nowego Testamentu. Wydanie z polską lokalizacja greckich haset, kluczem polsko-greckim oraz indeksem form czasownikowych, R. Popowski, Warszawa 2006 (skrót: Popowski).

\section{Literatura przedmiotu}

Barstad H.M., ad vocem רָּ, [w:] TDOT, vol. XIII, s. 618-630.

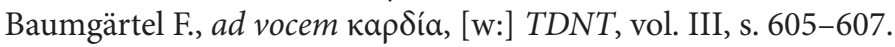

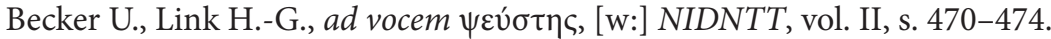

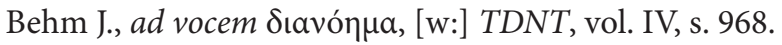

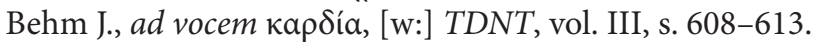

Behm J., ad vocem voũc, [w:] TDNT, vol. IV, s. 951-960.

Bertram G., ad vocem ä $\varphi \rho \omega v$, [w:] TDNT, vol. IX, s. 220-235.

Beyreuther E., ad vocem ка入ós, [w:] NIDNTT, vol. II, s. 102-105.

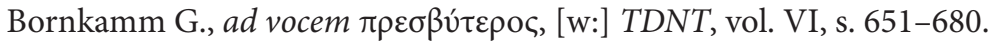

Botterweck G.J., ad vocem עִָּיָ, [w:] TDOT, vol. V, s. 448-481.

Büchsel F., ad vocem $\delta \tilde{\omega} \rho o v$, [w:] TDNT, vol. II, s. 166-167.

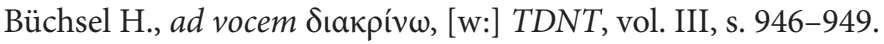

Bultmann R., ad vocem ả $\lambda_{\hat{\theta}} \theta \varepsilon$ เ , [w:] TDNT, vol. I, s. 238-247.

Cazelles H., ad vocem אִּנוּלֶ, [w:] TDOT, vol. I, s. 137-140.

Chou-Wee P., ad vocem אְִֶּ, [w:] NIDOTTE, vol. I, s. 303-3056.

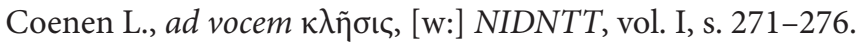

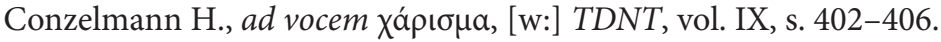

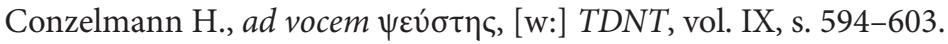

Delling G., ad vocem aiofávoual, [w:] TDNT, vol. I, s. 187-188.

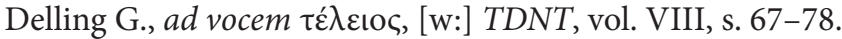

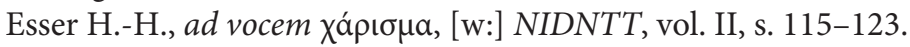


Fabry H.-J., ad vocem לב, [w:] TLOT, vol. VII, s. 399-437.

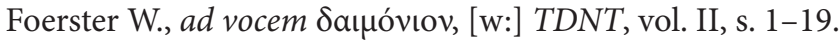

Fohrer G., ad vocem бoүía, [w:] TDNT, vol. VII, s. 476-496.

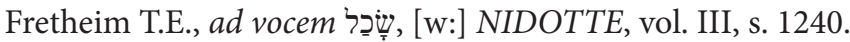

Fretheim T.E., ad vocem בין, [w:] NIDOTTE, vol. I, s. 641-642.

Fretheim T.E., ad vocem ירָעי, [w:] NIDOTTE, vol. II, s. 401-406.

Fretheim T.E., advocem רָצוֹן, [w:] NIDOTTE, vol. III, s. 182-183.

Fretheim T.E., ad vocem ירָע, [w:], NIDOTTE, vol. II, s. 401-406.

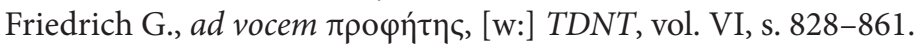

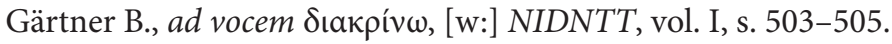

Goetzmann J., ad vocem ä $\varphi \rho \omega v$, [w:] NIDNTT, vol. III, s. 1023-1026.

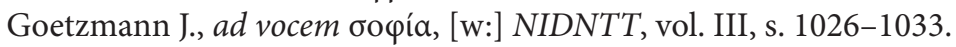

Gordon R.P., ad vocem בiv, [w:] NIDOTTE, vol. II, s. 346-350.

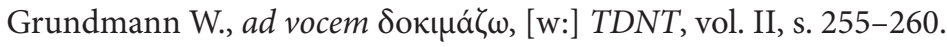

Grundmann W., ad vocem кa入ós, [w:] TDNT, vol. III, s. 536-550.

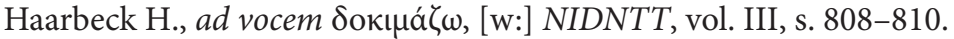

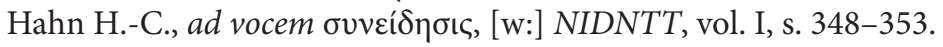

Harder G., ad vocem voũs, [w:] NIDNTT, vol. III, s. 122-130.

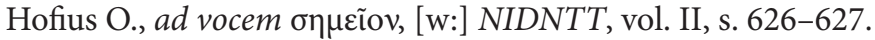

Höver-Johag I., ad vocem בiv, [w:] TDOT, vol. V, s. 296-317.

Jepsen A., ad vocem [מֶֶָ, [w:] TDOT, vol. I, s. 292-323.

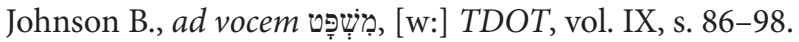

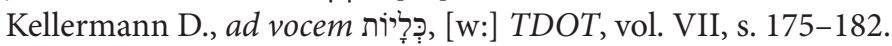

Luc A., ad vocem עָרָם II, [w:] NIDOTTE, vol. III, s. 536-538.

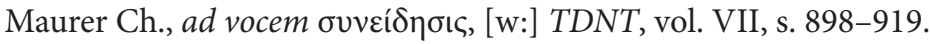

Müller D., ad vocem $\theta \varepsilon ́ \lambda \eta \mu a$, [w:] NIDNTT, vol. III, s. 1018-1023.

Müller H.-P., ad vocem חָָָָ, [w:] TDOT, vol. IV, s. 364-368.

Müller H.-P., ad vocem חָכְָמָה [w:] TDOT, vol. IV, s. 370-385.

Mundle W., ad vocem ảं 316.

O'Connell R. H., ad vocem טָָָׁ, [w:] NIDOTTE vol. II, s. 371-373.

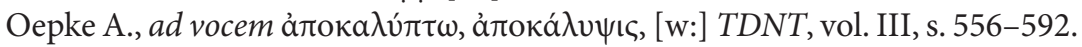

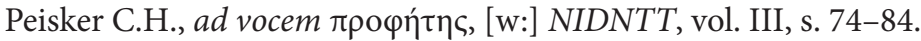

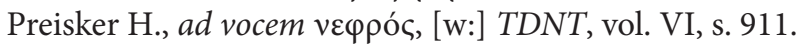

Quell G., ad vocem à $\lambda \hat{\theta} \theta \varepsilon ı$, [w:] TDNT, vol. I, s. 232-236.

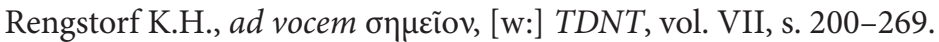

Ringgren H., ad vocem בין, [w:] TDOT, vol. II, s. 99-107.

Sæbø M., ad vocem חכם, [w:] TLOT, vol. I, s. 418. 


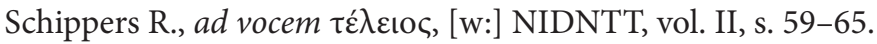
Schmid H.H., ad vocem [w:] TLOT, vol. I, s. 230-232.

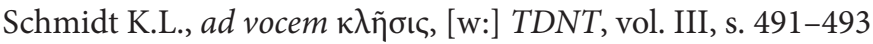
Schrenk G., ad vocem $\theta \dot{\lambda} \lambda \eta \mu \alpha$, [w:] TDNT, vol. III, s. 52-62.

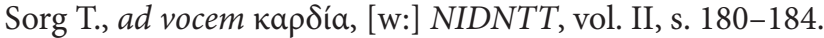

Thiselton A.C., ad vocem à $\lambda \dot{n} \theta \varepsilon\llcorner\alpha$, [w:] NIDNTT, vol. III, s. 874-902.

Vorländer H., ad vocem $\delta \tilde{\omega} \rho \mathrm{ov}$, [w:] NIDNTT, vol. II, s. 40-43. Wilckens U., ad vocem бoфía, [w:] TDNT, vol. VII, s. 496-526.

Wilson G.H., ad vocem חָדָָם [w:], NIDOTTE, vol. II, s. 128-131. Wilson G.H., ad vocem חָָכָדָה [w:] NIDOTTE, vol. II, s. 128-131. 